\title{
EXPLORING THE BOTTLENECK OF IRAN'S NATIONAL INNOVATION SYSTEM BY TOC THINKING PROCESS
}

\author{
Mansoureh ABDI ${ }^{\mathrm{a}}$, Alireza HASANZADEH ${ }^{\mathrm{a}}$, Ali-Asghar FANI ${ }^{\mathrm{b}}$, \\ Seyed Hassan GHODSI POOR ${ }^{c}$ \\ a Department of Information Technology Management, Tarbiat Modares University, Tehran, Iran \\ ${ }^{b}$ Department of Public Administration, Tarbiat Modares University, Tehran, Iran \\ 'Industrial Engineering Department, Amirkabir University of Technology, Tehran, Iran
}

Received 20 August 2012; accepted 06 October 2013

\begin{abstract}
This paper contributes to identify systematic problems in NIS using Thinking Process (TOC-TP) and to eliminate the bottlenecks, which results in improving the innovation process and efficiency of NIS. The Case study in this research is the NIS of Iran. The national documents of the innovation system were studied and all problems of NIS mentioned in documents were gathered. The causal relationships between the systematic problems were identified by the survey and grouped into 6 components by Exploratory Factor Analysis: weakness in technology diffusion mechanisms, the lack of centralized governance on science and technology policy, the government's pivotal role as an executor in education and research, weak laws and regulations in the field of research and technology, the lack of adequate financial resources in R\&D and the lack of any perspective on the creation of wealth and entrepreneurship among the actors of research and technology. Finally the bottleneck of Iran's NIS was recognized by Thinking Process tools: the small participation of private sector in research and education system as the result of government's pivotal role as an executor of Iran's national innovation system. So the researchers could diagnose the policy gaps related to the identified bottlenecks.
\end{abstract}

Keywords: NIS, bottleneck, TOC thinking process, Iran.

JEL Classification: O31, O32, N75.

\section{Introduction}

More than two decades have passed since the emergence of National Innovation System (NIS) as a new conceptual framework in science and technology studies in 1988. This concept was adopted in science and technology policies for the first time in Finland in 1992, and was

Corresponding author Mansoureh Abdi

E-mail: msabdi@modares.ac.ir 
mentioned as a tool for analysing the characteristics of the innovation process and guidance for policy makers (Sharif 2006). Following this trend, developing countries adopted this concept in their own science and technology policies However, the Porter and Stern's research in 2002 showed that improving the innovative capacity index has a direct positive impact on improving the competitiveness and GDP of countries (Porter, Stern 2002). This drew more attention to Innovation Systems as: "The network of institutions in the public and private sectors whose activities and interactions initiate, import, modify and diffuse new technologies" (Freeman 1987) at the national level. As Edquist has pointed out, "the institutional set-up related to innovation is one of the basic characteristics of NSI $\mathrm{s}^{1}$ " (Edquist 1997). If the links and interactions among the components involved in the mechanisms of innovation process are not effective, systematic defects will appear. This is more evident in developing countries due to the weaknesses in institutional interactions that affect the capacity of economic actors in the production and acceptance of new technologies; and given the limited resources (especially financial and human) and the need to set priorities to development plans in these countries, systematic defects become even more important. Therefore, many research are done to strengthen and increase the efficiency of NIS. But based on the Edquist research about all the OECD researches on NIS, there is No exclusive pattern for a successful implementation of this system, so it's not possible to provide a model for testing NIS in an empirical way (Sharif 2006). In fact, the innovation system includes all the institutions involved in the chain: from idea generation to commercialization, and according to (Polenakovik, Pinto 2010): "System performance is often determined by the weakest link in the chain. This means that policy interventions should focus on the weaknesses".

Looking at the process of innovation at the corporate level will illuminate the issue (Fig. 1).

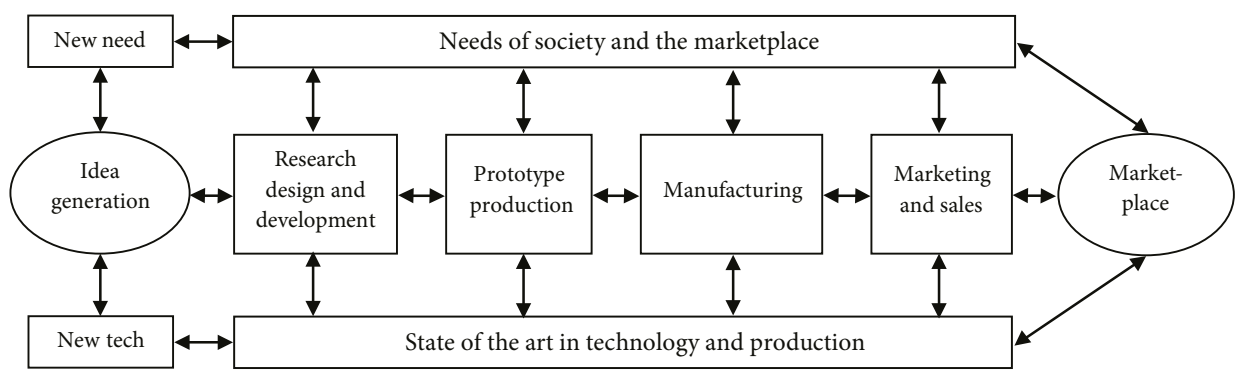

Fig. 1. Innovation process in corporate (Rothwell 1994)

If one of the rings in the chain of innovation process in corporate, such as prototype production, is weak (Fig. 1), the entire process from idea to product will be weak and no matter how well research and development is done there, it does not lead to manufacturing. Therefore, the overall performance of innovation process is affected by the system's bottleneck.

"National System of Innovation" equals to NIS 
The same syndrome can be generalized to the innovation system at the national level; but recognizing it would be very difficult. The analysis and diagnosis of the syndrome should be done systematically to promote the efficiency and effectiveness of the system. But research on systemic problems in NIS are scarce and mainly attempt to discuss the major problems in the system related to either the system's components individually. For example, (Lee, Park 2006) solely explore the contribution of $R \& D$ partnerships for a successful innovation in the middle part of Koreas' NIS, or in order to pay attention to the general system performance. As another example, Ghazinoory and Ghazinoori (2006) suggest some strategies to improve the performance of NIS in Iran using SWOT. These strategies have not considered the main bottlenecks of NIS, so most of them will only improve the performance of a single function without being able to improve the entire output of the innovation system in Iran. Furthermore, the limited financial resources must be distributed among all the mentioned strategies. Some other studies are mentioned in Table 1.

Table 1. Some methods for assessing and improving the innovation system ${ }^{2}$

\begin{tabular}{lll}
\hline \multicolumn{1}{c}{ Reference } & \multicolumn{1}{c}{ Method } & \multicolumn{1}{c}{ Result } \\
$\begin{array}{l}\text { Jegnenaars } \\
(1998)\end{array}$ & $\begin{array}{l}\text { System } \\
\text { dynamics }\end{array}$ & $\begin{array}{l}\text { In this paper, mechanisms of the innovation process were } \\
\text { modelled. They concluded that computer modelling may increase } \\
\text { human insight into the dynamics of the innovation process. }\end{array}$ \\
\hline $\begin{array}{l}\text { Nasierowski, } \\
\text { Arcelus (2003) }\end{array}$ & $\begin{array}{l}\text { Data } \\
\text { envelopment } \\
\text { analysis (DEA) }\end{array}$ & $\begin{array}{l}\text { The authors of this paper compared NIS efficiency with } \\
\text { productivity, GDP and population in 45 countries using DEA } \\
\text { and several indicators. }\end{array}$ \\
\hline $\begin{array}{l}\text { Lee, Tunzelmann } \\
\text { (2005) }\end{array}$ & $\begin{array}{l}\text { System } \\
\text { dynamics }\end{array}$ & $\begin{array}{l}\text { The paper developed a mathematical model for the national } \\
\text { innovation system of Taiwan using system dynamics and } \\
\text { concluded with some simulations of policy alternatives } \\
\text { confronting the Taiwanese government. }\end{array}$ \\
\hline $\begin{array}{l}\text { Abbasi } \text { et al. } \\
\text { (2011) }\end{array}$ & $\begin{array}{l}\text { Tobit and } \\
\text { Ordinary Least } \\
\text { Squares (OLS) } \\
\text { regression } \\
\text { models }\end{array}$ & $\begin{array}{l}\text { In this paper, virtual index is proposed for measuring the } \\
\text { relative innovativeness of countries. It concluded that the } \\
\text { OLS regression model would better explain the changes in the } \\
\text { performance of innovation- inefficient countries. }\end{array}$ \\
\hline $\begin{array}{l}\text { Chaminade } \text { et al. } \\
\text { (2012) }\end{array}$ & $\begin{array}{l}\text { Hierarchical } \\
\text { factor analysis }\end{array}$ & $\begin{array}{l}\text { This paper provides a framework to identify systemic problems } \\
\text { using hierarchical factor analysis in a system } \\
\text { of innovation for Thailand. }\end{array}$ \\
\hline
\end{tabular}

As shown in Table 1, the research focused on the general performance of NIS. While enhancing the performance of the whole innovation system requires heavy investment on all of the bottleneck and non-bottleneck stages, improving the performance depends only on the promotion of the bottleneck.

Theory of Constraints (TOC) is used to identify the Bottlenecks in the production line and Thinking Process (TP), as one of the TOC tools, is used to identify the constraints of management and policy as opposed to the physical limitations in the existing system.

\footnotetext{
2 Most of research have used survey and sent a questionnaire concerning the innovation system to the experts and analysed the results using statistical methods.
} 
TOC-TP approach contains the rigorous logic cause and effect rules in combination with the intuition and knowledge of the experts (Kim et al. 2008). Therefore this paper will try to use TOC-TP to identify systematic defects in NIS and to eliminate the bottlenecks which results in improving the innovation process and efficiency of NIS. The Case study in this research will be the NIS of Iran.

\section{Literature review}

\subsection{TOC thinking process}

The Theory of Constraints was first developed by Goldratt as a cause-and-effect logic tool. TOC views a system as a chain composed of many links that the strength of the chain is determined by the weakest link (Choe, Herman 2004). To use TOC as an applicable and practical theory, it should give appropriate responses to identify and to remove (or utilize) the system's constraints (Cox et al. 2005).

Three paradigms of TOC are logistic, global performance measures and thinking processes. There is a 5-Step process as the foundation for many of TOC's generic solutions (Cox et al. 2005): Step 1. Identify the constraint (the weakest link); Step 2. Decide how to exploit the constraint; Step 3. Subordinate and synchronize everything else to the above decisions; Step 4. Elevate the performance of the constraint; and Step 5. If in any of the above steps the constraint has shifted, go back to Step 1.

Goldratt believed that thinking process enables managers to tackle policy constraints by finding the answers to the basic questions relating to change - First: What to change? Second: What to change to? And third: How to cause the change? (Choe, Herman 2004).

The thinking process, which is part of the theory of constraints, leads to continuous improvement. In fact, the thinking process has been developed because, in addition to physical, there are managerial and political constraints in organizations; these constraints may be caused by applying inefficient patterns. It seems that TP is an appropriate starting point for identifying and removing the political constraints to improve the system's efficiency. In short, the thinking process in response to "what to change?", recommends identifying core conflict (constraint); in response to "what to change to?", recommends formulating a solution by injection into the system (change in the system); and in response to "how to cause the change?", recommends checking requirements of the proposed solutions.

Thinking process, in response to the above questions, makes use of five tools listed in Table 2.

Thinking process emphasized on improving and promoting the system's efficiency through resolving the managerial constraints. This led to use thinking process extensively in solving social and services problems. Research in this area discuss how TPs have been or could be applied to service sectors such as healthcare, education and public services (Kim et al. 2008). 
Table 2. TP tools (Mabin 1999; Choe, Herman 2004)

\begin{tabular}{|c|c|c|}
\hline Question & Tool & Implementation steps \\
\hline $\begin{array}{l}\text { What to } \\
\text { change? } \\
\text { Identify the } \\
\text { Weakest Link }\end{array}$ & $\begin{array}{l}\text { 1. Current } \\
\text { Reality Tree } \\
\text { (CRT) }\end{array}$ & $\begin{array}{l}\text { - Identifying 5-10 UnDesirable Effects (UDEs); } \\
\text { - Relating the UDEs through a logical chain of cause-and-effect } \\
\text { to root causes; } \\
\text { - Identifying a core problem (weakest link) that eventually produces } \\
70 \% \text { or more of the system's UDEs. }\end{array}$ \\
\hline \multirow{2}{*}{$\begin{array}{l}\text { What to } \\
\text { change to? } \\
\text { Design a } \\
\text { Stronger Link }\end{array}$} & $\begin{array}{l}\text { 2. Evaporating } \\
\text { Cloud (EC) }\end{array}$ & $\begin{array}{l}\text { - Clarifying the Core Conflict in the system; } \\
\text { - Creating solutions in which both sides win to develop the Desired } \\
\text { Effects (DE) as the primary solution. }\end{array}$ \\
\hline & $\begin{array}{l}\text { 3. Future Reality } \\
\text { Tree (FRT) }\end{array}$ & $\begin{array}{l}\text { - Converting the UDEs to DEs for testing the proposed solution; } \\
\text { - Executing the injections (lateral solutions) to minimize the new } \\
\text { UDEs arising from implementation of the primary solution. }\end{array}$ \\
\hline \multirow{2}{*}{$\begin{array}{l}\text { How to cause } \\
\text { the change? } \\
\text { Operationalize } \\
\text { this Stronger } \\
\text { Link into the } \\
\text { Chain }\end{array}$} & $\begin{array}{l}\text { 4. Prerequisite } \\
\text { Tree (PrT) }\end{array}$ & $\begin{array}{l}\text { - Defining the Intermediate Objectives(IOs) to achieve the system's } \\
\text { GOAL; } \\
\text { - Listing the obstacles to attain the IOs; } \\
\text { - Detecting the sequence of actions to overcome the obstacles. }\end{array}$ \\
\hline & $\begin{array}{l}\text { 5. Transition } \\
\text { Tree (TrT) }\end{array}$ & $\begin{array}{l}\text { - Provide an action plan that set the actions step-by-step to reach the } \\
\text { goal (realizing the intermediate objectives identified in PrT); } \\
\text { - Providing a rationale for the implementation process; } \\
\text { - Coordinate the actions with the objectives. }\end{array}$ \\
\hline
\end{tabular}

\subsection{National Innovation System}

NIS is "the network of institutions in the public and private sectors whose activities and interactions initiate, import, modify and diffuse new technologies" (Freeman 1987) at the national level. Also, NIS is a framework to analyse factors forming technological innovations by considering the impact of national environmental factors (such as universities, financial and credit systems, public and private research institutes, and government policies) in addition to relationships and interactions between institutions.

Like the other systems of links, interactions and cooperative relationships between the components (the actors in the NIS) are not effective, systematic defects (or problems) will appear. Many studies have investigated the systematic defects and factors influencing the inefficient performance of innovation systems. Woolthuis provided a framework to determine where the system's bottlenecks lie and how they are addressed (which actors and failures) (Woolthuis et al. 2005). But as the authors said: the framework should further be tested in practice.

Generally all research proposed a set of principals in NIS but not necessarily the precise agreements and tools for testing the hypothesis (Edquist 2001).

In this paper, NIS problems regarding innovation policy approach is identified based on six functions (Chaminade, Edquist 2005): 1. Policy formulation; 2. Performing R\&D; 3. Facilitating and financing, R\&D; 4. Promotion of human resource development and mobility; 5. Technology diffusion; and 6. Promotion of technological entrepreneurship. The paper used thinking process as a systematic approach to identify the bottleneck of NIS.

3 UDEs are visible results that are negative in relation to the system's goal or the necessary conditions to achieve that goal. Most often UDEs reflect poor system performance and are symptomatic of one or two underlying systemic or core problems (Shoemaker, Reid 2005). 


\subsection{TP application in NIS}

Although many researches have been done to diagnose the problems with NIS and its promotion in different countries, it is very interesting that they have scarcely ever looked at the problems of NIS in a systematic way. In other words, the innovation system which itself believes in multilateral interactions and interfaces between the components and institutions to develop innovation has rarely been studied systematically. Since changing and modifying any component of an innovation system, has positive and negative effects on components performance, these components cannot be individually modified. In fact, systematic view suggests that individual policy instruments applied in isolation are unlikely to have a dramatic impact on overall system performance (Polenakovik, Pinto 2010). Therefore, a systematic approach is necessary to analyse comprehensively the discrepancies in the components and relationships in the national innovation systems.

The main goal of this paper is to present a method for performance improvement and promotion of the system. According to Goldratt's Theory of Constraints, improving the bottlenecks is the best strategy to promote the system performance (Goldratt 1994). This paper is identifying the bottlenecks of NIS in a systematic method, and providing some policies to remove them. So we face soft managerial and political Constraints.

The Literature on thinking process claims that TP tools pursue strict logic rules by using the precise cause-and-effect thinking and if combined with the intuition and knowledge of decision-makers can even solve complex problems in an efficient and effective way (Kim et al. 2008). Considering the kind of constraint in the system which is "political", TP could be applied. Besides, this tool focuses on the cause-and-effect relationship in a list of UDEs (and not on prioritizing, ranking or arranging UDEs (Goldratt 1994)). Therefore, it inclusively analyses all the identified problems in different parts of NIS.

Hitherto, many case studies and research on practical application of TP in various fields have been done (Kim et al. 2008):

- Business system in a single case organization for example (Choe, Herman 2004);

- Specific functional areas such as manufacturing and production, supply chain management and human resource management for example (Rahman 2002);

- Service sector such as healthcare, education and public services for example (Shoemaker, Reid 2005).

But we couldn't find a case of using TP at the national level. Therefore, this paper not only gives a new vision in analysing the problems in NIS, but is a practical experience of applying $\mathrm{TP}$ in a national case.

The methodological orientation is categorized Enhancement/multi-methodology. Because the paper aims to extend the understanding and use of TP principles by proposing the integration with other methodologies: Exploratory Factor Analysis is used for identifying and categorizing the NIS problems alongside experts' idea. This integration will improve the process of building Current Reality Tree. 


\section{Suggested algorithm}

According to Dettmer, each TP tool is potentially valuable in its own right, without regard to its contribution in a sequenced use of tools (Choe, Herman 2004). We apply CRT (illustrated in Table 1) as one of the most used TP tools. This tool is particularly effective if the constraint is a policy as opposed to a physical limitation in the system. But in the process of building a CRT by using the traditional approach, two unfortunate matters often arise. Firstly, sometimes it is difficult to accept that a problem is related to poor management practices. Secondly, Building a CRT is regarded as too complicated and too time consuming.

To overcome such issues, several authors advise the use of Communications Current Reality Tree which demonstrates the main problem by describing the relationship between observed UDEs and the underlying core conflict. Both approaches have been much in use (Kim et al. 2008).

Many research up to now have been done to examine the multi-methodological use of TP with other well established tools, methods and methodologies, and for strengthening the theoretical foundations of TP. Some researchers have used TP tools to improve other methodologies. Some researchers have also used other methodologies in compensating for TP's weaknesses in identifying the core problem and generating ideas (to solve the core conflict). For example, by combining System Thinking, System Dynamic, OR/MS, TRIZ with TP (Kim et al. 2008), they have attempted to achieve improved outcomes in making strategic and operational decisions.

This study attempts to use CRT in the following stepwise process in order to identify the core problem in the system (Table 3):

Step 1. Primary Studies: the first step in the proposed algorithm is to make a list of the existing undesirable effects. To identify the core problem, all areas should be examined simultaneously to determine the constraint of the system. The data that could include the national documents in the field of science and technology policy - with focusing on the innovation system - is analysed using one of the methods of Text Analysis to identify undesirable effects. Therefore, UDEs are categorized according to the functions of NIS; and the causal relationships between them in each function are determined by the experts. The output of this step would be the main problems in any function.

Step 2. Extracting 5-10 UDEs: to identify the causal relationships between the problems in the system, the traditional approach has been followed. But in order to extract 5-10 UDEs from the main problems of the system (step 0), the correlation between the ultimate root causes (main problems) in various categories (NIS functions) will be determined by using one of the statistical methods.

Step 3. Recognizing the system's bottleneck: the relations between undesirable effects are drawn in a chain of cause-and-effect logic. The Bottleneck in the system is identified in this step. It can include one or two core problems (Shoemaker, Reid 2005) and is mainly the cause of over $70 \%$ of UDEs in the system (Choe, Herman 2004).

4 The EC and CRT are the most used TP tools (Kim et al. 2008) 
Table 3. Proposed algorithm for recognizing the bottleneck of Iran's NIS

\begin{tabular}{lll}
\hline \multicolumn{1}{c}{ Step } & \multicolumn{1}{c}{ Purpose } & Implementation tool \\
\hline Primary studies & $\begin{array}{l}\text { UDEs identification } \\
\text { Divide the UDEs into categories based on } \\
\text { NIS functions }\end{array}$ & Text Analysis Method \\
\hline $\begin{array}{l}\text { Extracting 5-10 UDEs } \\
\text { in system }\end{array}$ & $\begin{array}{l}\text { Consideration of the experts' ideas } \\
\text { Identify the correlation between UDEs }\end{array}$ & Statistical Method \\
\hline $\begin{array}{l}\text { Recognizing the system's } \\
\text { bottleneck }\end{array}$ & $\begin{array}{l}\text { Relate UDEs through a logical chain of cause } \\
\text { and effect to root causes } \\
\text { Identify a core problem that eventually } \\
\text { produces 70\% or more of the system's UDEs }\end{array}$ & CRT \\
\hline
\end{tabular}

\section{Case study in Iran}

\subsection{Introducing Iran's NIS}

Each National Innovation System should perform some functions and activities for the national innovation development; these functions and activities can be traced and explained in different levels. At the macro level, the most important functions of national innovation system are creation, diffusion and exploitation of knowledge and innovation; these subjects are classified in various forms in different references. We use NIS functions classified by OECD (1999) and the status of each function in Iran will be briefly reviewed:

\section{- Policy Formation}

The structure of science, technology and innovation policy-making in Iran has not been integrated and various institutions are involved. The Expediency Discernment Council passes macro policies in science and technology. The Parliament passes the necessary legislation and submits it to the government for implementation. The High Council of Cultural Revolution (directly appointed by the leadership) also compiles all the policies related to science and technology and all its legislation is considered as a parliamentary law. Supreme Council of Science, Research and Technology is also responsible for coordinating all Government activities in the field of Science and Technology. The Ministry of Science, Research and Technology is responsible for planning, guidance, support, assessment, monitoring, review and development of the policies and strategic priorities in research and technology. Other ministries and government agencies cooperate by making policies and planning for $\mathrm{R} \& \mathrm{D}$, science and technology development and most of them have R\&D units. In recent years, the president has also established a deputy department of science and technology whose duties strongly overlap with those of other institutions ${ }^{5}$.

\footnotetext{
5 This deputy was established in 2006 with the aim of coordinating the ministries, as well as matching supply with demand of science and technology. But in practice, it performs such administrative activities in support of scientific journals, researchers, knowledge bases enterprises that overlap with the ministries (especially the Ministry of Science, Research and Technology).
} 
Iranian policy-makers have placed special emphasis on a rapid development of emerging technologies, particularly nanotechnology which can be considered as a successful example in formulating technology policy (Ghazinoory, Ghazinouri 2009) ${ }^{6}$. Cross-sectoral structure of the National Iranian Nanotechnology Initiative (NINI) was the most important aspect in developing Nanotechnology in Iran. All sectors involved in developing nanotechnology including research, training, industrial and investing institutes participated in policy-making and execute phase. So cross-sectoral cooperation was increased and loss of capital was prevented. NINI adopted a diffusion-oriented approach leading national determination to remove the barriers to innovation in nanotechnology. So, despite the multiple bottlenecks in NIS, the case of nanotechnology shows that if proper policy has been formulated and responsible institution (such as TCO) resolved the bottlenecks, achieving the world-wide success is possible. However, limited resources do not allow following this procedure.

\section{- Performing R\&D}

Typically, the number of patents and R\&D projects (or investments) can clear the status of knowledge development in the country. So far the patent system in Iran has been based on announcement; therefore, the statistics available in the patent office could not be relied on. In 2010, Iran has registered 7 patents in $\mathrm{USPTO}^{7}$ and has generally registered 88 patents from 1989 to 2010 (Ghazinoory et al. 2010). Moreover, about 17000 R\&D projects were performed by the Iranian government agencies of universities in 2011.

Another indicator, describing this function, is the number of graduate theses and doctoral dissertations; about 35000 theses were proposed and approved in Iran in 2011. It is worthy of note that the number of universities and students has been increasing in Iran in recent years; therefore, the number of theses has also increased. But since their subjects are not problem oriented, they have no significant impact on the development of research and economy in Iran. Nevertheless, the Iranian government agencies are trying to support theses by determining their research priorities and therefore solve the problems in industry and economy.

- Facilitating and financing R\&D

R\&D budget of research funds from the GDP in 2010 was equivalent to 0.73 percent. In 2010 and 2011 the Iranian government, in addition to the allocation of research findings to organizations and ministries, has obliged the state organizations or companies to allocate

\footnotetext{
6 The government's attention to nanotechnology in Iran started in 2001 when Iranian President Khatami made Technology Cooperation Office (TCO) responsible for coordination of developmental activities for nanotechnology in the country. In 2003, after extensive studies and analysis, the TCO recommended creation of a council and was given a task of defining the direction for nanotechnology development in Iran. Additionally, the TCO has concluded that nanotechnology development in Iran requires national initiative. The National Iranian Nanotechnology Initiative (NINI) was subsequently approved by Iranian cabinet in July 2005 (Ghazinoory, Heydari 2008). As a result of the NINI's supports, many Iranian universities and institutions focused on different courses related to nanotechnology. About 18 university educational courses, 90 research institutions, 5 incubators, 40 specific laboratories, and 30 specific medias have been established as some infrastructures of nanotechnology (Ghazinoory, Farazkish 2010). According to the vision of the program, nanotechnology should be used for the creation of wealth and improvement of people's quality of life, and achieving a proper position among 15 countries advanced in nanotechnology in the world by 2015 (Ghazinoory, Soofi 2012). As a result of these activities, in 2012, Iran was ranked $9^{\text {th }}$ in the worldwide ranking nanotechnology articles.

7 United States Patent and Trademark Office
} 
about $1 \%$ of their total budget to research activities, based on national priorities. Unfortunately, this objective has not been fulfilled and government spends very little of its GDP in research and development.

From 2000, the Ministry of Culture and Higher Education was changed to The Ministry of Science, Research and Technology (MSRT), Iranian Research Organization for Science and Technology (IROST) was divided into some sections; its national duty was changed to the Deputy of MSRT and its provincial branches were changed to science and technology parks. The Center for Innovation and Technology Cooperation which is under the President's control, plays an important role in transferring, development and localization of a number of important technologies. Engineering Services companies are also the interfaces between industry, technology innovators and manufacturers of machinery, industrial equipment and structures; and the permission to work is submitted to them by the Ministry of Industry, mine and trade.

\section{- Promotion of human resource development and mobility}

119 universities are run by the government in Iran; among them the University of Applied Sciences has 739 campuses and Payame Noor University has 550 campuses, also 600 small universities (semi-state and private) are working across the country. The sum of all academic units is over 2400 .

Until 2011, about 4.1 million students have been studying at all levels of higher education (public and private) and the largest numbers of them are undergraduate students. Among the educational groups that have the largest student population, Technical and Engineering group is in the second place. But due to insufficient practical training in education (which is mostly theoretical), engineering graduates mainly lack innovative capabilities and are not successful in applying their skills in R\&D activities (Ghazinoory, Ghazinoori 2006). Some problems of universities in Iran include financial problems and lack of communication with the universities abroad and the emigration of professors and graduate students. In fact one of the most important problems in the innovation system of Iran is brain drain and due to the disproportion between research and financial facilities in Iran and those provided in developed countries. Although there is no hope to return after the emigration.

\section{- Technology diffusion}

The number of scientific conferences is a good indicator to evaluate the diffusion of knowledge. Also one of the main parameters that determine the status of this function is the number of scientific papers in Iran. In 2010 more than 18 thousand scientific papers of Iranian researchers were indexed in Thomson Reuters. Also, about 21 thousand Iranian scientific papers were indexed in Scopus and this clearly shows Iran's scientific production growth. Another indicator of knowledge diffusion is the amount of network activities. In fact, the collaboration networks entered into the science and technology policy and management in Iran in the mid-1990s. The first major program to create cooperation networks was in 1997, by Iran's Scientific Research Council when networking research laboratories in the field of biotechnology, information technology, earthquake and materials were designed and implemented. However, the number of successful and active networks in Iran does not exceed 10 . 
The number of scientific journals can also be considered as an indicator determining the status of this function. In 2011, the number of scientific journals in Iran became 800, which represents the growth of knowledge diffusion in Iran.

Obviously, the original model of technology transfer in Iran is transferring R\&D achievements - that includes tacit knowledge - from universities and research institutions to the companies. But due to the lack of awareness and lack of adequate attention to the technology diffusion mechanisms such as the knowledge spillover, the diffusion process in Iran does not work properly.

\section{- Promotion of technological entrepreneurship}

The traditional system of education in Iran is not based on business and trade, and the majority of graduates are trained for employment (especially in the state-owned sectors). However, because of the unemployment crisis among the graduates in recent years, entrepreneurship has become a subject of great concern and several institutions have been created for this purpose. For example, the entrepreneurship centres at university can be noted which are launched based upon focusing on the entrepreneurship courses for university students, students competitions in the development of business plans, speeches by the entrepreneurs and similar activities. Incubators and technology parks are also created to promote entrepreneurship by the government ministries, universities and provinces. In order to support the entrepreneurship, especially in high tech areas, the government has enacted a law to support the knowledge-based firms. According to this law, the knowledge-based firms are exempt from taxes, customs duties, surcharges, and enjoy special privileges in public companies tenders. In 2011, the government has decided to support these firms by establishing the Innovation and Development Fund financed from the annual foreign-exchange reserves. In order to help the newly established companies in areas of high technology, the government allocated $\$ 3$ billion dollars to the first three years of the fund's activity, and made long-term loans to active companies. This policy helps to accelerate the transfer of knowledge to wealth. In addition, this fund should actively participate in, or establish the venture capitals in Iran. Another part of this law exempts all the knowledge-based firms from paying taxes up to 15 years; and some facilities are considered for products insurance and employees insurance; therefore, there will be less problems in the way of establishing companies in areas of high tech, and their survival in the turbulent environment of Iran will be possible. So despite the progress in promoting the technological entrepreneurship over the last two decades, Iran's NIS faces the challenge of converting knowledge to wealth (Soofi, Ghazinoory 2013).

\subsection{Implementation of algorithm in Iran}

The proposed algorithm is done with larger and broader systematic size (analysing problems) at the national level in this study. Therefore, the subject finds strategic importance and it becomes necessary to consider the perspective of experts in this area to identify problems and their relationships. This is taken into account in all steps of algorithm. 


\section{Step 1. Primary studies}

Studies to identify UDEs was done on five scientific papers (Ghazinoory, Ghazinoori 2008, 2006; Manteqi et al. 2010; Mirblook et al. 2008; Soltani 2004), 2 reports (Molanezhad 2010; Mani 2004) and 15 national documents in the field of science and technology policy (some including Iran's Vision Statement for Horizon $2025^{8}$, Iran's comprehensive scientific plan ${ }^{9}$ and Industrial Development Strategy of $\operatorname{Iran}^{10}$ ). The conducted analyses were focused on the innovation system dimension based on the functions of NIS (mentioned in the previous section), respectively. The items that have six desired characteristics are UDEs (Shoemaker, Reid 2005):

1. A complete statement;

2. An effect (not a presumed cause) to show that there is some possibility of changing;

3. Which that exists in today's reality precisely as stated;

4. Negative or undesirable in its own right;

5. Not a presumed solution;

6. A single effect with no and, because, due to, or as a result of phrases needed to clarify. The main problems resulting from the review of NIS documents, included 71 UDEs (Appendix I). Then the causal relationship between UDEs in each function was identified by the means of Focus Group method (based on the views of 5 experts in the field of science and technology policy-making). So, in addition to finding all the problems mentioned in documents (mostly highlighted in the form of SWOT and the challenges of NIS), the survey has also been used. Finally, 19 variables were identified as the root problems (Table 4).

Table 4. The root problems of Iran's NIS

\begin{tabular}{|c|c|}
\hline Category & Root problems (focus group) \\
\hline $\begin{array}{l}\text { Policy } \\
\text { formulation }\end{array}$ & $\begin{array}{l}\text { V1: The lack of a centralized institution responsible for policy-making in } \\
\text { science, technology and innovation in the country. } \\
\text { V2: The lack of a proper system for monitoring and evaluating in science, } \\
\text { technology and innovation activities in the country. }\end{array}$ \\
\hline $\begin{array}{l}\text { Facilitating and } \\
\text { financing } R \& D\end{array}$ & $\begin{array}{l}\text { V3: Complexity of regulations governing research and technology. } \\
\text { V4: Lack of legal, cultural and structural infrastructure, required for the } \\
\text { support of intellectual property. } \\
\text { V5: Non-recognition of the main priorities in directing research and } \\
\text { technological activities. } \\
\text { V6: Excessive reliance on government sources for financing the research and } \\
\quad \text { technology. } \\
\text { V7: Low share of Iran's R\&D from GDP. }\end{array}$ \\
\hline Performing R\&D & $\begin{array}{l}\text { V8: Low number of specialized R\&D units in the country. } \\
\text { V9: Lack of necessary and enough incentives to increase the share of private } \\
\text { sector in research. } \\
\text { V10: The lack of commercialization and business view in the managers of } \\
\text { research centres (especially in governmental). }\end{array}$ \\
\hline
\end{tabular}

\footnotetext{
8 http://maslahat.ir/DocLib2/Approved\%20Policies/Offered\%20General\%20Policies/policy\%2006-07-1382\%20 Iran\%20Vision\%201404.aspx (in Farsi)

9 http://www.iranculture.org/fa/Default.aspx?current=viewDoc\&currentID=736 (in Farsi)

${ }^{10}$ http://www.spac.ir/portal/File/ShowFile.aspx?ID=2165fe0d-29c5-49f7-9a3e-3f75aa19f10d (in Farsi)
} 
Continued Table 4

\begin{tabular}{|c|c|}
\hline Category & Root problems (focus group) \\
\hline $\begin{array}{l}\text { Promotion of } \\
\text { human resource } \\
\text { development and } \\
\text { mobility }\end{array}$ & $\begin{array}{l}\text { V11: Inappropriateness of some of the goals and the content of educational } \\
\text { system with national requirements (particularly the lack of prospect for } \\
\text { training skilled people in new technologies). } \\
\text { V12: Aggregation of the roles of the investor, manager, standard-maker, and } \\
\text { evaluator of the higher education all of which are played by the government. }\end{array}$ \\
\hline $\begin{array}{l}\text { Promotion of } \\
\text { technological } \\
\text { entrepreneurship }\end{array}$ & $\begin{array}{l}\text { V13: Educational system's insistence upon transferring knowledge instead of } \\
\text { creating areas of invention and innovation. } \\
\text { V14: Bureaucratic atmosphere prevailing in the country's R\&D centres } \\
\text { and universities about innovative activities inconsistent with the } \\
\text { entrepreneurial morale. } \\
\text { V15: Absence of institutions for technological and financial and venture capital } \\
\text { for entrepreneurs. }\end{array}$ \\
\hline $\begin{array}{l}\text { Technology } \\
\text { diffusion }\end{array}$ & $\begin{array}{l}\text { V16: Very limited familiarity of national policy makers and experts with the } \\
\text { concept and the importance of technology diffusion in innovation system. } \\
\text { V17: Weak international communications in scientific, research and education } \\
\text { outputs. } \\
\text { V18: Absence of clusters and networks of scientific, industrial and technological } \\
\text { research. } \\
\text { V19: Lack of mechanisms to facilitate the diffusion of technology (including } \\
\text { a strong system of intellectual property and laws to facilitate technology } \\
\text { diffusion). }\end{array}$ \\
\hline
\end{tabular}

\section{Step 2. Extracting 5-10 UDEs}

Drawing the Current Reality Tree must start with the 5-10 UDEs. Considering the high number of root problems identified in the previous stages (19 variables), those UDEs that can be combined should be identified and the number of root problems should be reduced. For this purpose, the correlation between variables (root problems) was determined by using the questionnaire (experts' opinions). The statistical survey society includes researchers, academics and executives who were active in NIS-related areas such as science, technology policy-making and technology management. Information about these experts was extracted from the database of Iran Association for Management of Technology (IRAMOT) which has been the only active association in this field and is running since 2003. The electronic questionnaire was sent to about 300 people. 157 questionnaires were received back and out of this number, 136 questionnaires were reliable. 16 faculty members (private and state universities), 45 researchers (industrial and governmental), 39 managers (from the country's science and technology policy-makers and technology management sector of private companies) and 36 students (MS and PhD in the field of S\&T policy-making and technology management) had responded to the reliable questionnaire (Table 5). The validity of the questionnaire was confirmed with 0.804 for the Kaiser-Meyer-Olkin measure of sampling adequacy and its reliability was confirmed by Chronbach's alpha, equal to 0.859 . The Structure Matrix (output of SPSS software) for Exploratory Factor Analysis that shows the correlation between 19 variables in 6 components is presented in Table 6. 
Table 5. Population demographic information (electronic questionnaire)

\begin{tabular}{|c|c|c|c|c|c|}
\hline \multirow{2}{*}{ Gender } & Female & 28 & \multirow{4}{*}{$\begin{array}{c}\text { Age } \\
\text { (years old) }\end{array}$} & Under 30 & 42 \\
\hline & Male & 108 & & $30-40$ & 62 \\
\hline \multirow{5}{*}{ Profession } & Researcher & 45 & & $40-50$ & 21 \\
\hline & Student (MS and PhD) & 36 & & Over 50 & 11 \\
\hline & Manager & 39 & \multirow{7}{*}{$\begin{array}{l}\text { The field of } \\
\text { education }\end{array}$} & Executive management and MBA & 26 \\
\hline & \multirow[t]{2}{*}{ Faculty members } & \multirow[t]{2}{*}{16} & & Technology management & 53 \\
\hline & & & & Science and technology policy & 11 \\
\hline \multirow{4}{*}{$\begin{array}{l}\text { Education } \\
\text { Level }\end{array}$} & $\begin{array}{l}\text { Science and technology } \\
\text { policy-makers and } \\
\text { technology manager (BS) }\end{array}$ & 14 & & $\begin{array}{l}\text { Future study and } \\
\text { entrepreneurship }\end{array}$ & 4 \\
\hline & Student (MS) & 4 & & $\begin{array}{l}\text { Management (industrial, } \\
\text { business, strategic) }\end{array}$ & 9 \\
\hline & MS & 77 & & $\begin{array}{l}\text { Engineering (mechanical, } \\
\text { electronic, industrial, civil, } \\
\text { polymer and chemical) }\end{array}$ & 23 \\
\hline & $\mathrm{PhD}$ & 41 & & $\begin{array}{l}\text { Other (Statistics, Economics, } \\
\text { Sociology) }\end{array}$ & 10 \\
\hline
\end{tabular}

Table 6. Structure Matrix from SPSS

\begin{tabular}{ccccccc}
\hline & \multicolumn{6}{c}{ Component } \\
\cline { 2 - 7 } & 1 & 2 & 3 & 4 & 5 & 6 \\
\hline V1 & 0.153 & $\mathbf{0 . 7 7 2}$ & -0.036 & -0.195 & -0.154 & -0.073 \\
V2 & 0.223 & $\mathbf{0 . 6 8 2}$ & -0.058 & -0.219 & -0.284 & -0.343 \\
V3 & 0.210 & 0.192 & 0.162 & $-\mathbf{0 . 7 6 7}$ & -0.278 & -0.293 \\
V4 & 0.232 & 0.340 & 0.070 & $\mathbf{- 0 . 7 7 7}$ & -0.107 & -0.121 \\
V5 & 0.256 & $\mathbf{0 . 7 0 0}$ & 0.325 & -0.137 & -0.184 & -0.095 \\
V6 & 0.036 & 0.064 & $\mathbf{0 . 7 6 8}$ & -0.196 & -0.284 & -0.133 \\
V7 & 0.265 & 0.080 & 0.407 & -0.257 & $\mathbf{- 0 . 7 1 5}$ & -0.083 \\
V8 & 0.145 & 0.279 & 0.138 & -0.072 & $-\mathbf{0 . 7 8 1}$ & -0.224 \\
V9 & 0.353 & 0.280 & $\mathbf{0 . 5 7 4}$ & 0.152 & -0.049 & -0.546 \\
V10 & 0.459 & 0.408 & 0.198 & 0.231 & -0.234 & $\mathbf{- 0 . 5 1 8}$ \\
V11 & 0.332 & 0.326 & 0.219 & -0.103 & 0.068 & $\mathbf{- 0 . 6 1 7}$ \\
V12 & 0.507 & 0.151 & $\mathbf{0 . 5 6 6}$ & 0.003 & -0.136 & -0.383 \\
V13 & 0.200 & 0.089 & 0.127 & -0.147 & -0.270 & $\mathbf{- 0 . 8 4 0}$ \\
V14 & 0.424 & 0.010 & 0.432 & -0.200 & -0.316 & $\mathbf{- 0 . 6 4 5}$ \\
V15 & 0.476 & 0.366 & -0.011 & -0.285 & $-\mathbf{0 . 6 0 7}$ & -0.445 \\
V16 & $\mathbf{0 . 7 3 5}$ & 0.133 & 0.165 & -0.157 & -0.100 & -0.169 \\
V17 & $\mathbf{0 . 7 4 4}$ & 0.162 & 0.045 & -0.013 & -0.145 & -0.334 \\
V18 & $\mathbf{0 . 6 1 1}$ & 0.397 & -0.014 & 0.002 & -0.446 & -0.258 \\
V19 & $\mathbf{0 . 6 7 3}$ & 0.369 & 0.286 & -0.383 & -0.298 & -0.223 \\
\hline
\end{tabular}

Extraction method: Principal Component Analysis.

Rotation method: Oblimin with Kaiser Normalization. 
Conceptual analysis of the six separate categories is also very interesting:

Component 1: weakness in technology diffusion mechanisms

This component includes problems related to the mechanisms of technology diffusion such as the lack of policies in the technology diffusion, the lack of regional, international and scientific cooperation between the research institutions within and outside the country, the absence of scientific, industrial and technological networks, and lack of mechanisms to facilitate the diffusion of technology.

Component 2: the lack of centralized governance on science and technology policy

The lack of a unique institution for policy-making and planning in the field of science, technology and innovation, besides the absence of monitoring and evaluating system for scientific and research activities (the lack of definition and implementation of indicators to measure the output, the impact and the outcome of scientific and research activities) and therefore, the non-recognition of national priorities in research activities are considered in this component.

Component 3: the government's pivotal role as an executor in education and research

The highlighted role of government in all functions of NIS, a high reliance on government funds (in fact on oil revenues) and the lack of attention to encourage and stimulate R\&D in the private sector created a vicious cycle that is summarized in this factor.

\section{Component 4: weak laws and regulations in the field of research and technology}

Problems related to the highly complex bureaucracy in all the scientific and research activities are placed in this category - due to this problem the formation of mechanisms to develop venture capital and to support the research activities are weakened. A logical relationship between legal authorities and R\&D centres has become hard to establish; legal and cultural infrastructural needs for valuation and exchange of intangible assets are not met and intellectual property rights are neglected.

Component 5: the lack of adequate financial resources in $R \& D$

About R\&D expenses in Iran it should be said that even having to allocate a little of the organizations budget (funding) to $\mathrm{R} \& \mathrm{D}$ has failed to have much impact on the $\mathrm{R} \& \mathrm{D}$ share of GDP. The shortage of specialized R\&D units and absence of institutions for financial supports and venture capitals have also prevented sufficient funds to be spent on R\&D in Iran.

Component 6: the lack of any perspective on the creation of wealth and entrepreneurship among the actors of research and technology

The lack of an effective and efficient relationship between universities (and research institutions) and the industry caused the creation of value among managers become very pale. Besides, disproportion between the content of the education system and the need for training new specialists in the fields of science and technology, and the lack of attention to promoting entrepreneurship (invention and Innovation) and bureaucratic atmosphere as a deterrent factor in innovative activities were in this component. 


\section{Step 3. Recognizing the bottleneck of system}

The relations between undesirable effects are mapped in a chain of cause-and-effect logic. The central problem in the system which is the cause of more than $70 \%$ of UDEs is identified in this step. The Current Reality Tree is shown in Figure 2. The core conflict of the system, which causes 0.83 undesirable effects in the system, follows as: The small participation of private sector in research and education system of Iran's national innovation system.

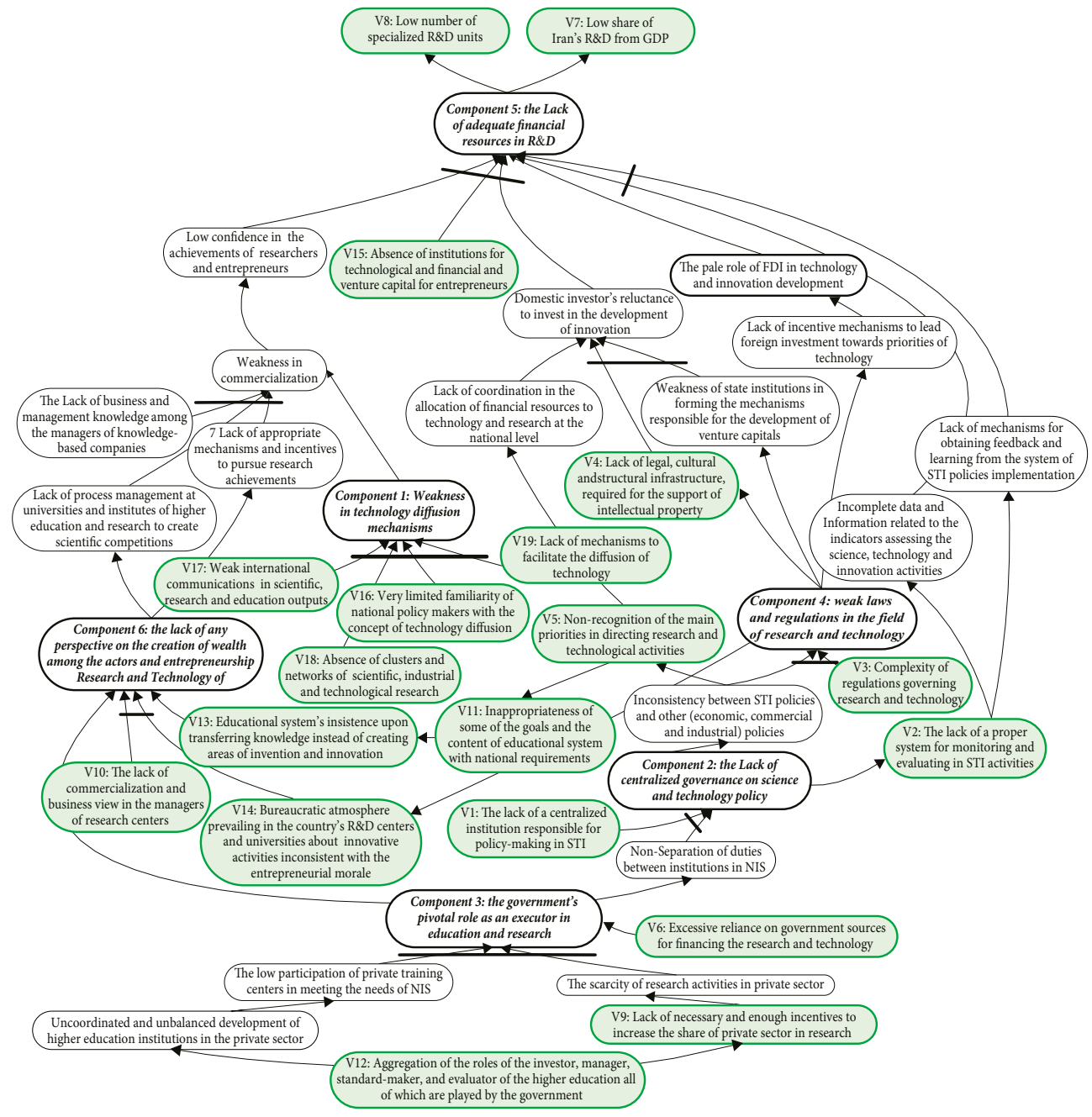

The six components are bold.

The box of root problems is green.

Fig. 2. Current Reality Tree of Iran's NIS 


\section{Conclusions}

The studies on the problems of Iran's NIS were mainly related to the system's components individually or to the general system performance. But the perspective in NIS studies has not been systematic. This paper tried to recognize the bottleneck of Iran's NIS using TOC thinking process (as the systematic approach to identify the managerial and political constraints). Also, to remove the obstacle of wide problems associated with NIS in building Current Reality Tree (too complicated and too time consuming (Kim et al. 2008)), Exploratory Factor Analysis (EFA) has been used for categorizing the systems' problems. Therefore "the applying TP in a national case" in addition to "develop thinking process tool in building Current Reality Tree by Exploratory Factor Analysis" are the novelties of this paper.

Based on the findings of this research, the main bottleneck (core conflict) of Iran's NIS is the small participation of private sector in research and education system of Iran's national innovation system; or in the other hand, is "the government's pivotal role as an executor in education and research". This problem was mentioned as one of the top ranked obstacles to develop S\&T in previous studies related to NIS (Ghazinoory, Ghazinoori 2006; Mirblook et al. 2008; Manteqi et al. 2010; Hajihoseini et al. 2011; Abbasi et al. 2012; Soofi, Ghazinoory 2013).

This result was discussed at "meeting of experts" and was approved by most of them. They believed that because the NIS functions in Iran are state-owned, even the abundance of the human and financial resources do not increase the outputs of this system. According to TOC thinking process, this is quite normal because all the efforts and investments in recent years in Iran's NIS, only improved some functions such as human training or R\&D (especially in state sector). However, since these functions are non-bottleneck, the outputs of NIS such as the innovations and the wealth derived from them are not increased. But the key point is that about 90 to 94 percent of Iran's economy is run by the public and state sectors. In fact, the private sector in addition to having a small participation - 6 to 10 percent - is a contractor for the state sector, and all its activities are highly dependent upon state services and support. Now the question is: Whether we can expect this small and weak private sector to break the government monopoly in education and research in order to increase the capacity of bottleneck in Iran's NIS?

It seems that the answer to this question is negative. Iran's private sector will only be able to have large impacts on national innovation system if its contribution of the whole national economy is increased.

There are many experiences that show the existing policy instruments used to stimulate and support innovation, they cannot be effective in the context of state economy.

For example, when the Iranian government decided to pay the costs of registering patents in the Euro patent and US patent in order to support the commercialization of research achievements, researchers registered the patents with the government's financial support. But they did not take any steps for actual commercialization of their research achievements and the registered patents were just added to their resumes. However, based on the policies of $44^{\text {th }}$ principle of Constitution, the government should divest the authority of state corporations to the private and cooperative sectors. On one hand, the private sector contributions in economy will be increased. On the other hand, government could spend the proceeds from divesting to develop the infrastructures of S\&T. Although, the proposed policies resolving 
the bottlenecks (as injections) need to be studied carefully and will be concluded using the other TP tools (listed in Table 2) in another article.

TOC-TP seems to be an effective tool to find the main bottleneck of NIS; this can also be used in other countries. With this method, the bottlenecks of the system can be identified and the limited resources of the country can be used merely to increase the capacity of the bottleneck, so that the output of innovation system can increase with more speed and lower cost.

Building evaporating cloud (EC) to recognize the core conflict in NIS could be a future study that can be done in this area. Research on new ways to generate ideas for resolving the conflict identified (the output of EC) is another research to develop and promote TP.

\section{References}

Abbasi, F.; Attar, H.; Hajihoseini, H. 2012. Commercialization of new technologies: the case of Iran, International Journal of Technology Management \& Sustainable Development 11(2): 191-202. http://dx.doi.org/10.1386/tmsd.11.2.191_1

Abbasi, F.; Hajihoseini, H.; Haukka, S. 2011. Use of virtual index for measuring efficiency of innovation systems: a cross-country study, International Journal of Technology Management \& Sustainable Development 9(3): 195-212. http://dx.doi.org/10.1386/tmsd.9.3.195_1

Chaminade, C.; Edquist, C. 2005. From theory to practice: the use of systems of innovation approach in innovation policy [online], [ cited 8 October 2012], Centre for Innovation, Research and Competence in the Learning Economy (CIRCLE), Paper No. 2005/02, Lund University, Sweden. Available from Internet: http://www.circle.lu.se/upload/CIRCLE/workingpapers/200502_Chaminade_Edquist.pdf

Chaminade, C.; Intarakumnerd, P.; Sapprasert, K. 2012. Measuring systemic problems in National Innovation Systems: an application to Thailand, Research Policy 41(8): 1476-1488.

http://dx.doi.org/10.1016/j.respol.2012.04.004

Choe, K.; Herman, S. 2004. Using Theory of Constraints tools to manage organizational change: a case study of EURIPA labs, International Journal of Management \& Organizational Behaviour 8(6): 540-558.

Cox, J. F.; Mabin, V. J.; Davies, J. 2005. A case of personal productivity: illustrating methodological developments in TOC, Journal of Human Systems Management 24(1): 39-65.

Edquist, C. 1997. Systems of innovations: technologies, institutions and organizations. London: Pinter. 15 p.

Edquist, C. 2001. The systems of innovation approach and innovation policy: an account of the state of the art, Lead Paper Presented at the DRUID Conference, 12-15 June 2001, Aalborg, Denmark, 1-24.

Freeman, C. 1987. Technology policy and economic performance: lessons from Japan. Pinter Publishers. 1 p.

Ghazinoory, S.; Abdi, M.; Bagheri, S. K. 2010. Promoting Nanotechnology patenting: a new experience in national innovation system of Iran, Journal of Intellectual Property Rights (JIPR) 15: 464-473.

Ghazinoory, S.; Farazkish, M. 2010. A model of technology strategy development for Iranian nano-composite companies, Technological and Economic Development of Economy 16(1): 25-42.

http://dx.doi.org/10.3846/tede.2010.02

Ghazinoory, S.; Ghazinoori, S. 2006. Developing Iran's government strategies for strengthening the national system of innovation using SWOT analysis, Science and Public Policy 33(7): 529-540. http://dx.doi.org/10.3152/147154306781778759

Ghazinoory, S.; Ghazinoori, S. 2008. Extracting strategies for modification of the National Innovation System of Iran based on comparative studies, Journal of Science and Technology Policy 1(1): 64-80 (in Farsi).

Ghazinoory, S.; Ghazinouri, R. 2009. Nanotechnology and sociopolitical modernity in developing countries; case study of Iran, Technological and Economic Development of Economy 15(3): 395-417. http://dx.doi.org/10.3846/1392-8619.2009.15.395-417 
Ghazinoory, S.; Heydari, E. 2008. Potential impacts of nanotechnology development in Iran, Technology and Society Magazine 27(4): 37-44. http://dx.doi.org/10.1109/MTS.2008.930886

Ghazinoory, S.; Soofi, A. 2012. Modifying BSC for national nanotechnology development: an implication for "social capital" role in NIS theory, Technological and Economic Development of Economy 18(3): 487-503. http://dx.doi.org/10.3846/20294913.2012.707630

Goldratt, E. M. 1994. It's not luck. The North River Press. 12 p.

Hajihoseini, H.; Mohammadi, M.; Abbasi, F.; Elyasi, M. 2011. Analysis of Iranian innovation system's governance based on innovation policy making cycle, Journal of Science and Technology Policy 4(1): 33-48 (in Farsi).

Janszen, F. H. A.; Degenaars, G. H. 1998. A dynamic analysis of the relations between the structure and the process of National Systems of Innovation using computer simulation: the case of the Dutch biotechnological sector, Research Policy 27(1): 37-54. http://dx.doi.org/10.1016/S0048-7333(98)00023-7

Kim, S.; Mabin, V. J.; Davies, J. 2008. The theory of constraints thinking processes: retrospect and prospect, International Journal of Operations \& Production Management 28(2): 155-184. http://dx.doi.org/10.1108/01443570810846883

Lee, J. D.; Park, C. 2006. Research and development linkages in a national innovation system: factors affecting success and failure in Korea, Technovation 26(9): 1045-1054. http://dx.doi.org/10.1016/j.technovation.2005.09.004

Lee, T. L.; Tunzelmann, N. V. 2005. A dynamic analytic approach to national innovation systems: the IC industry in Taiwan, Research Policy 34(4): 425-440. http://dx.doi.org/10.1016/j.respol.2005.01.009

Mabin, V. 1999. Goldratt's Theory of Constraints “Thinking Processes”: a systems methodology linking soft with hard, in Proc. of the $17^{\text {th }}$ International Conference of the System Dynamics Society and $5^{\text {th }}$ Australian and New Zealand Systems Conference, 20-23 July 1999, Wellington, New Zealand.

Mani, S. 2004. A national system of innovation in the making: an analysis of the role of government with respect to promoting domestic innovations in the manufacturing sector of Iran [online], [cited $7 \mathrm{Au}-$ gust 2012]. United Nations University, Institute for New Technologies, Netherlands. Available from Internet: http://www.intech.unu.edu/publications/discussion-papers/2004-12.pdf

Manteqi, M.; Hasani, A.; Boushehri, A. 2010. Identifying the policy making challenges in the National Innovation System of Iran, Journal of Science and Technology Policy 2(3): 87-102 (in Farsi).

Mirblook, A.; Rezaee, R.; Mousavi, R. 2008. Comparative study of NIS in Iran and other countries, Journal of Management and Human Resource in Oil Industry 2(3): 32-66 (in Farsi).

Molanezhad, M. 2010. A brief review of science and technology and SMEs development in I.R. Iran, The Inter-Sessional Panel of the United Nations Commission on Science and Technology for Development, 15-17 December 2010, Geneva, Switzerland.

Nasierowski, W.; Arcelus, F. J. 2003. On the efficiency of national innovation systems, Socio-Economic Planning Sciences 37(3): 215-234. http://dx.doi.org/10.1016/S0038-0121(02)00046-0

OECD 1999. Managing National Innovation Systems [online], [cited 8 April 2012]. Organization for Economic Co-operation and Development Publications. 36 p. Available from Internet: http://echo. iat.sfu.ca/library/oecd99_managing_National_IS.pdf.

Polenakovik, R.; Pinto, R. 2010. The National Innovation System and its relation to small enterprises: the case of the Republic of Macedonia, World Review Science, Technology and Sustainable Development 7(1): 91-107.

Porter, M. E.; Stern, S. 2002. National innovative capacity. The Global Competitiveness Report 2001-2002 (World Economic Forum). Oxford University Press, 102-119.

Rahman, S. 2002. The theory of constraints: thinking process approach to developing strategies in supply chains, International Journal of Physical Distribution and Logistics Management 32(10): 809-828. http://dx.doi.org/10.1108/09600030210455429 
Rothwell, R. 1994. Towards the fifth-generation Innovation Process, International Marketing Review 11(1): 7-31. http://dx.doi.org/10.1108/02651339410057491

Sharif, N. 2006. Emergence and development of the National Innovation Systems concept, Research Policy 35(5): 745-766. http://dx.doi.org/10.1016/j.respol.2006.04.001

Shoemaker, T. E.; Reid, R. A. 2005. Applying the TOC Thinking Process: a case study in the government sector, Human Systems Management 24: 21-37.

Soltani, B. 2004. Research and technology in Iran's NIS, $51^{\text {th }}$ Symposium of Research and Scientific Centers and Universities in Iran, Tehran, Iran (in Farsi).

Soofi, A. S.; Ghazinoory, S. 2013. Science and Innovations in Iran: development, progress, and challenges. Palgrave Macmillan press. 83 p. http://dx.doi.org/10.1057/9781137030108

Woolthuis, R. K.; Lankhuizen, M.; Gilsing, V. 2005. A system failure framework for innovation policy design, Technovation 25(6): 609-619. http://dx.doi.org/10.1016/j.technovation.2003.11.002

\section{APPENDIX I}

Main problems and root problems of Iran's NIS

\begin{tabular}{|c|c|c|}
\hline Category & Main problems (from the documents) & Root problems (focus group) \\
\hline Policy formulation & $\begin{array}{l}\text { 1-1 The lack of a centralized institution responsible for } \\
\text { policy-making in science, technology and innovation } \\
\text { in the country. } \\
\text { 1-2 Non-Separation of duties between institutions } \\
\text { in NIS. } \\
\text { 1-3 Non-Determination of priorities in science, } \\
\text { technology and innovation in the country. } \\
\text { 1-4 The lack of a proper system for monitoring } \\
\text { and evaluating in science, technology and innovation } \\
\text { activities in the country. } \\
\text { 1-5 Lack of mechanisms for obtaining feedback } \\
\text { and learning from the system of science, technology } \\
\text { and innovation policies implementation. } \\
\text { 1-6 Incomplete data and Information related to } \\
\text { the indicators assessing the science, technology } \\
\text { and innovation activities. }\end{array}$ & $\begin{array}{l}\text { V1: The lack of a centralized } \\
\text { institution responsible for policy- } \\
\text { making in science, technology and } \\
\text { innovation in the country. } \\
\text { V2: The lack of a proper system } \\
\text { for monitoring and evaluating in } \\
\text { science, technology and innovation } \\
\text { activities in the country. }\end{array}$ \\
\hline $\begin{array}{l}\text { Facilitating and } \\
\text { financing R\&D }\end{array}$ & $\begin{array}{l}\text { 2-1 Lack of legal, cultural and structural } \\
\text { infrastructure, required for the support } \\
\text { of intellectual property. } \\
\text { 2-2 Non-Prediction of the required mechanisms } \\
\text { for valuing and exchanging intangible assets. } \\
\text { 2-3 The method of announcement in registration } \\
\text { of the patents rather than examination method. } \\
\text { 2-4 Inappropriate division of intellectual property } \\
\text { affairs (the lack of focus on the executive branch) } \\
\text { in the country. } \\
\text { 2-5 Excessive reliance on government sources for } \\
\text { financing the research and technology. } \\
\text { 2-6 Lack of diversity in income sources of universities } \\
\text { and research institutes. } \\
\text { 2-7 Research and researcher's intense concentration } \\
\text { in Tehran. }\end{array}$ & $\begin{array}{l}\text { V3: Complexity of regulations } \\
\text { governing research and technology. } \\
\text { V4: Lack of legal, cultural and } \\
\text { structural infrastructure, required for } \\
\text { the support of intellectual property. } \\
\text { V5: Non-recognition of the main } \\
\text { priorities in directing research and } \\
\text { technological activities. } \\
\text { V6: Excessive reliance on } \\
\text { government sources for financing } \\
\text { the research and technology. } \\
\text { V7: Low share of Iran's R\&D from } \\
\text { GDP. }\end{array}$ \\
\hline
\end{tabular}


Continued Appendix I

\begin{tabular}{l} 
Category \\
\hline \multicolumn{1}{c}{ Main problems (from the documents) } \\
2-8 Low share of Iran's R\&D from GDP. \\
and research. \\
2-10 Non-recognition of the main priorities in directing \\
research and technological activities. \\
2-11 Lack of financial resources distribution \\
commensurate with the missions. \\
2-12 Lack of financial and policy mechanisms focused \\
on the demand side. \\
2-13 Lack of coordination in the allocation of financial \\
resources to technology and research at the national \\
level. \\
2-14 Lack of incentive mechanisms to lead foreign \\
investment towards priorities of technology. \\
2-15 Investment in low and medium-tech industries. \\
2-16 Complexity of regulations governing research \\
and technology. \\
2-17 The lack of a defined economic system in support \\
of research activities. \\
2-18 Weakness of state institutions in forming the \\
mechanisms responsible for the development of \\
venture capitals. \\
2-19 The lack of a sensible and legal relation between \\
patents and R\&D centres. \\
2-20 Outdated national standards that do not match \\
the international standards.
\end{tabular}

Performing R\&D 3-1 Low number of specialized R\&D units in the country.

3-2 The limited number of researchers in relation to the population (especially in industrial sector).

3-3 The scarcity of research activities in private sector.

3-4 Lack of necessary and enough incentives to increase the share of private sector in research.

3-5 The High share of government sector in R\&D and innovative activities.

3-6 The lack of commercialization and business view in the managers of research centres (especially in governmental).

3-7 Lack of appropriate mechanisms and incentives to pursue research achievements.

3-8 Lack of process management at universities and institutes of higher education and research to create scientific competitions.

Promotion of human resource development and mobility
4-1 Aggregation of the roles of the investor, manager, standard-maker, and evaluator of the higher education all of which are played by the government.

4-2 Not prevailing the systematic view in defining academic fields.

4-3 Weakness and failure of human resource management (recruiting, training, distribution, promotion and maintenance).

4-4 The lack of independent validation institutions (lack of specific processes for validation of research institutions).
Root problems (focus group)
V8: Low number of specialized
R\&D units in the country. V9: Lack of necessary and enough incentives to increase the share of private sector in research. V10: The lack of commercialization and business view in the managers of research centres (especially in governmental).
V11: Inappropriateness of some of the goals and the content of educational system with national requirements (particularly the lack of prospect for training skilled people in new technologies). V12: Aggregation of the roles of the investor, manager, standardmaker, and evaluator of the higher education all of which are played by the government. 
Continued Appendix I

\begin{tabular}{ll}
\hline Category & \multicolumn{1}{c}{ Main problems (from the documents) } \\
\hline & 4-5 Inappropriateness of some of the goals and \\
the content of educational system with national \\
requirements (particularly the lack of prospect \\
for training skilled people in new technologies). \\
4-6 Disarrangement of Theses and Dissertations \\
for economic, social and technical needs of the \\
country. \\
4-7 The lack of attention to reinforce the research and \\
innovation morale in educational system. \\
5-1 Educational system's insistence upon transferring \\
knowledge instead of creating areas of invention \\
and innovation. \\
technological \\
entrepreneurship Lack of entrepreneurial morale among students, \\
besides offering specialized trainings. \\
5-3 The lack of Defined communication between \\
R\&D centres and commercial enterprises for \\
commercializing the technologies. \\
5-4 The Lack of business and management \\
knowledge among the managers of knowledge-based \\
companies. \\
5-5 The Weakness of institutions that offer specialized \\
consulting to the newly established firms. \\
5-6 Absence of institutions for technological and \\
financial and venture capital for entrepreneurs. \\
5-7 Lack of sufficient experience in the field of venture \\
capital. \\
5-8 The pale presence of incubators in Iran's economy. \\
5-9 Bureaucratic atmosphere prevailing in the country's \\
R\&D centres and universities about innovative activities \\
inconsistent with the entrepreneurial morale. \\
5-10 Obstacles in the tax law and labour law.
\end{tabular}

Root problems (focus group)

V13: Educational system's insistence upon transferring knowledge instead of creating areas of invention and innovation.

V14: Bureaucratic atmosphere prevailing in the country's $R \& D$ centers and universities about innovative activities inconsistent with the entrepreneurial morale.

V15: Absence of institutions for technological and financial and venture capital for entrepreneurs. consulting to the newly established firms.

5-6 Absence of institutions for technological and financial and venture capital for entrepreneurs. 5-7 Lack of sufficient experience in the field of venture capital.

$5-9$ Bureaucratic atmosphere prevailing in the country's

$R \& D$ centres and universities about innovative activities 5-10 Obstacles in the tax law and labour law.

Technology
diffusion
technology (including a strong system of intellectual
property and laws to facilitate technology diffusion).
6-2 The lack of licensing and technology transfer
centres at universities and R\&D institutions.
6-3 The lack of strong Publishers that can have
international participations.
6-4 The Lack of effective policies and tax incentives
for technology transfer and diffusion.
6-5 Limited number of systems to monitor
implementation, evaluation and Audit of technology.
6-6 Absence of clusters and networks of scientific,
industrial and technological research.
6-7 Lack of proper communication among the active
scientific research institutes in the country.
6-8 Lack of effective monitoring of technologies
appropriate to the national needs.
6-9 Disharmony and parallel work in the field
of technology transfer and development at the
national level.

V16: Very limited familiarity of national policy makers and experts with the concept and the importance of technology diffusion in innovation system.

V17: Weak international communications in scientific, research and education outputs. V18: Absence of clusters and networks of scientific, industrial and technological research.

V19: Lack of mechanisms to facilitate the diffusion of technology (including a strong system of intellectual property and laws to facilitate technology diffusion). 
End of Appendix I

\begin{tabular}{|c|c|c|}
\hline Category & Main problems (from the documents) & Root problems (focus group) \\
\hline & $\begin{array}{l}\text { 6-10 Low penetration of new technologies in all } \\
\text { aspects of education system. }\end{array}$ & \\
\hline & $\begin{array}{l}6-11 \text { Inability to use up-to-date technology in new } \\
\text { projects. }\end{array}$ & \\
\hline & $\begin{array}{l}\text { 6-12 Limited number of scientific networks to use } \\
\text { the collective power of faculty members. }\end{array}$ & \\
\hline & $\begin{array}{l}\text { 6-13 Lack of intermediate and industrial institutions } \\
\text { in knowledge transfer. }\end{array}$ & \\
\hline & 6-14 Lack of technology diffusion centres. & \\
\hline & $\begin{array}{l}\text { 6-15 Very limited familiarity of national policy makers } \\
\text { and experts with the concept and the importance of } \\
\text { technology diffusion in innovation system. }\end{array}$ & \\
\hline & $\begin{array}{l}\text { 6-16 Absence of strategies to technology acquisition } \\
\text { in different sectors. }\end{array}$ & \\
\hline & $\begin{array}{l}\text { 6-17 The weakness of the science and technology } \\
\text { announcement system in the diffusion of scientific } \\
\text { and technological achievements. }\end{array}$ & \\
\hline & $\begin{array}{l}\text { 6-18 Weaknesses in international cooperation in the } \\
\text { field of technology policy and using other countries' } \\
\text { experiences in this area. }\end{array}$ & \\
\hline & $\begin{array}{l}\text { 6-19 Weak international communications in scientific, } \\
\text { research and education outputs. }\end{array}$ & \\
\hline & 6-20 Absence of Marketing and Technology & \\
\hline & Certificate Registration. & \\
\hline
\end{tabular}

Mansoureh ABDI has a PhD degree in S\&T policy from Tarbiat Modares University. She received her BSc in Industrial Engineering from BuAli Sina University and her MSc in Industrial Engineering from Tarbiat Modares University. Her main research interests are science and technology policy (special for NIS) and strategy formulating (in macro level and soft areas such as Elites Communication and Consultation). Her thesis was about policy extracting to promote NIS in Iran by theory of constraints.

Alireza HASANZADEH is an Associated Professor in the Department of Information Technology Management, Tarbiat Modares University, Tehran, Iran. He has PhD in Systems Management. He is working on information technology impacts, strategic information systems, technologies for knowledge management, etc.

Ali-Asghar FANI is an Assistant Professor in the Department of Public Administration, Tarbiat Modares University, Tehran, Iran. His $\mathrm{PhD}$ is organizational behavior and human resource management. His main research interests are economics of education, reengineering of education management, intelligent schools, reinforcing R\&D morale sense in education etc.

Seyed Hassan GHODSI POOR is a Professor in Industrial Engineering Department, Amirkabir University of Technology, Tehran, Iran. He is an expert in science and technology policy, strategy formulating using hard techniques in soft areas such as analytic hierarchy process, decision support system and multi-criteria decision making in policy extracting. He has several books (in Farsi) and tens of papers (in English and Farsi) in these areas. 